\title{
Deficiency of caspase 3 in tumor xenograft impairs therapeutic effect of measles virus Edmoston strain
}

\author{
Biao Wang ${ }^{1}$, Xu Yan ${ }^{2}$, Qingguo Guo ${ }^{1}$, Yan Li ${ }^{3}$, Haiyan Zhang ${ }^{4}$, JiSheng Xie ${ }^{5}$, Xin Meng ${ }^{1}$ \\ ${ }^{1}$ Department of Biochemistry and Molecular Biology, College of Basic Medical Sciences of China Medical University Shenyang, \\ P.R. China \\ ${ }^{2}$ Department of Prosthodontics, School of Stomatology, China Medical University, Shenyang, P.R. China \\ ${ }^{3}$ Department of Oncology, Tumour Angiogenesis and Microenvironment Laboratory (TAML), First Affiliated Hospital, Liaoning \\ Medical College, Jinzhou, P.R. China \\ ${ }^{4}$ Department of Geriatrics, The First Affiliated Hospital, China Medical University, Shenyang, P.R. China \\ ${ }^{5}$ Department of Ecsomatics, Youjiang Medical College for Nationalities, Baise City, P.R. China \\ Correspondence to: \\ Xin Meng, e-mail: kinmou0423@hotmail.com \\ Keywords: caspase-3, interferon alpha, oncolytic therapy, apoptosis, measles virus Edmonston strain
}

Received: January 20, 2015

Accepted: March 07, 2015

Published: March 26, 2015

\section{ABSTRACT}

The oncolytic measles virus Edmonston (MV-Edm) strain shows considerable oncolytic activity against a variety of human tumors. In this study, we report MV-Edm is able to trigger apoptosis pathways in infected tumor cells and elucidate the roles of cellular apoptosis in the whole oncolytic process. We also show that activated caspase 3, a key executioner of apoptosis, plays key roles in the oncolytic virotherapy. Activated caspase 3 can accelerate viral replication in cervical cancer cells and enhance the killing effects of the virus. Deficiency of caspase 3 either in tumor cells or in tumor xenograft significantly desensitized tumor to oncolysis with MV-Edm. In the infected cells, caspase 3 regulates interferon a release, which can inhibit viral replication in neighboring tumor cells. We propose that caspase-3 activation enhances the oncolytic effects of MV-Edm, thus inhibiting tumor growth in mice.

\section{INTRODUCTION}

Cervical cancer (CC) is one of the most common and lethal gynecological malignancies in both developing and developed countries [1,2]. And oncovirotherapy is being touted as the future of cancer treatment, which has limited side effects and involves the use of the virus to specifically replicate in the tumor cells and kill the cells lytically. An oncolytic virus is a set of virus that preferentially infects and kills cancer cells rapidly and lytically [3-8]. Moreover, some of these viruses are being used as tools for cancer therapies in current clinical trials $[9,10]$, such as lymphoma, ovarian cancer, mesothelioma, breast cancer, and renal and hepatocellular carcinoma $[9,11-14]$.

Measles virus (MV) is a $16 \mathrm{~kb}$ single-stranded, negative-sense, enveloped RNA virus of the genus Morbillivirus within the family Paramyxoviridae. Many previous studies have shown that live attenuated Edmonston B strain of measles virus (MV-Edm) has potent and specific oncolytic activity against a variety of human cancer cells, including malignant lymphoma, multiple myeloma, mesothelioma, epithelial ovarian cancer, breast cancer, liver cancer and glioma [11, 15-19]. MV-Edm is selectively oncolytic, causing extensive syncytium formation and cell killing in a variety of human tumor cancer cells but minimal cytopathic damage in nontransformed cells such as normal skin fibroblasts, hepatocytes, mesothelial cells from the peritoneal cavity, and peripheral blood lymphocytes $[11,14,19,20]$.

As we know, both the pathogenic wild-type MV and the attenuated vaccine strain MV-Edm enter cells by binding through their $\mathrm{H}$ attachment protein to one of two cellular receptors, signaling lymphocyte activation molecule (SLAM, also known as CD150) or CD46 [21-23]. Actually, CD46 is frequently overexpressed on human cancer cells and barely expressed on normal cells (such as, fibrocytes and lymphocytes).

Human type I interferon (IFN- $\alpha / \beta$ ) is crucial for host defense against viral infections. IFN- $\alpha / \beta$ have been proved 
to inhibit gene expression and the production of progeny virions of the measles virus vaccine strain, including Edmonston tag strain [24, 25]. It was reported that MV vaccine strains can induce significantly higher levels of type I IFN than wild-type MV [26].

Some studies have confirmed that oncolytic therapy is often accompanied by a process of inducing cell apoptosis [5, 27-29]. In our previous study, the whole process of oncolytic therapy for renal carcinoma was accompanied by apoptosis [14]. However, it still remains unclear whether the apoptosis induced by virus infection affects the virus replication and whether the cellular apoptosis could contribute to the oncolytic therapy.

As a key executioner in apoptosis, caspase 3 is considered an essential event during cellular apoptosis. We hypothesized that the cellular apoptosis could be involved in the process of cell death induced by MV-Edm infection and the caspase 3 mediated apoptosis could attenuate the innate immunity of host cells, thereby, accelerating the virus replication in cancer cells.

In this study, we evaluated the roles of caspase 3 mediated apoptosis in the oncovirotherapy in human CC cell lines and xenografts. Our data have demonstrated caspase 3 mediated apoptosis promoted the rapid replication of virus by inhibition of IFN production. We believe this newly discovered role of caspase- 3 mediated apoptosis has profound implications for oncolytic cancer therapy.

\section{RESULTS}

\section{CD46 is overexpressed on human CC cell lines}

CD46 expression in the normal human lung fibroblast cell line NHLF, human cervical cancer cell lines $\mathrm{SiHa}, \mathrm{C}-33 \mathrm{~A}$ and primary human cervical cancer cells of CC-5 was analyzed by flow cytometry. CD46 was expressed on the surface of all human cervical cancer cell lines and primary human cervical cancer cells: 97\% in $\mathrm{SiHa}, 90 \%$ in C-33A, and $91-94 \%$ in CC-5 cells $(n=3)$. However, only $7 \%$ in NHLF demonstrated positive expression of CD46 (Figure 1). These results demonstrated that human cervical cancer cell lines and primary cervical cancer cells expressed higher levels of CD46 than normal cells.

\section{MV-Edm have a strong ability to induce cytopathic effects (CPEs) and cell death in CC cells}

The cytopathic effects (CPEs) caused by MV-Edm replication were investigated in the normal human NHLF, SiHa, C-33A, and CC-5 cells. Cells were infected with MV-Edm at multiplicities of infection (MOIs) of 0.1 and 1 for 96 hours and then stained with crystal violet. MV-Edm infection caused dramatic CPEs in an MOI-dependent manner ( $n=3$; Figure 2a). However, normal human cell line NHLF showed minimal CPEs after MV-Edm infection (Figure 2a), even treated with MV-Edm at higher MOI. We further determined the cell viability after infection with the MV-Edm using the MTS Assay every 24 hours for 96 hours. The results showed that MV-Edm infection at MOI of 0.1 and 1 demonstrated a great cell growth inhibition in $\mathrm{SiHa}, \mathrm{C}-33 \mathrm{~A}$, and primary CC-5 cells from 48 hours to 96 hours $(n=3$; Figure $2 \mathrm{~b}-2 \mathrm{e})$. And MV-Edm at MOI of 1 has more inhibitory effects on the cell growth. Then, to confirm whether or not the cellular growth inhibition was caused by cell killing effects of MV-Edm, the cells were collected and counted with Trypen Bule staining method after infection with MV-Edm at different times. Briefly, SiHa, C-33A, and primary CC-5 cells were seeded at $1 \times 10^{4}$ cells/well in a 6 -well plate and incubated overnight. Then the cells were infected with MV-Edm at MOIs of 0.1 and 1, respectively. Collect all the cells every 24 hours and count the cells. At $72 \mathrm{~h}$ and $96 \mathrm{~h}$, the cells-alive infected by MV-Edm were statistically lower in number than that in MOCK group $(P<0.05, n=3$; Figure 2e and Figure S-1). And at $96 \mathrm{~h}$,
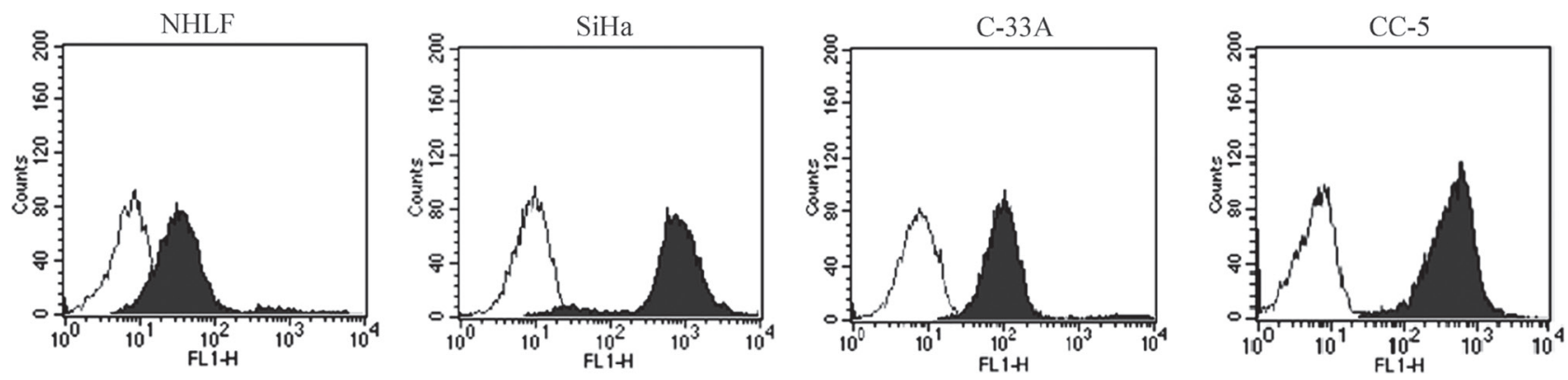

Figure 1: CD46 expression on the human cervical cancer $(C C)$ cell lines $\mathrm{SiHa}$ and $\mathrm{C}-33 \mathrm{~A}$, primary human CC cells of CC-5, and normal human lung fibroblast cell line NHLF. Relatively higher levels of CD46 receptor were observed on the human CC cell lines SiHa and C-33A, as well as the primary cancer cell CC-5 than that on normal cell line NHLF. The blank histograms show the measured fluorescence of cells incubated with an isotype control (detailed), and the black histograms represent cells labeled with an antiCD46 fluorescein isothiocyanate antibody. The analysis was performed by flow cytometry. 
cells in the $\mathrm{MOI}=1$ group was obviously lower in number than that in $\mathrm{MOI}=0.1$ group $(P<0.05, n=3$; Figure $2 \mathrm{e}-2 \mathrm{f}$ and Figure S-1).

\section{Role of Caspase- 3 in the cellular apoptosis induced by MV-Edm infection in vitro}

To investigate the function of caspase 3 in viralinfected CC cells, caspase 3 was down-regulated by short hairpin RNA (shRNA) against caspase 3 (sh-c3), which was confirmed by Western blot analysis (Figure $3 \mathrm{a}$ and Figure S-2a). The SiHa and C-33A cells were divided into four groups: the wild-type $\mathrm{SiHa} / \mathrm{C}-33 \mathrm{~A}$ cells without any treatments $\left(\mathrm{SiHa}^{\mathrm{wt}} / \mathrm{C}-33 \mathrm{~A}^{\mathrm{wt}}\right), \mathrm{SiHa} / \mathrm{C}-33 \mathrm{~A}$ cells transfected with scrambled shRNA ( $\left.\mathrm{SiHa}^{\text {sh-cont }} / \mathrm{C}-33 \mathrm{~A}^{\text {sh-cont }}\right), \mathrm{SiHa} / \mathrm{C}$ $33 \mathrm{~A}$ cells transfected with $\mathrm{sh}-\mathrm{c} 3$ ( $\left.\mathrm{SiHa}^{\mathrm{sh}-\mathrm{c} 3} / \mathrm{C}-33 \mathrm{~A}^{\mathrm{sh}-\mathrm{c} 3}\right)$ and $\mathrm{SiHa} / \mathrm{C}-33 \mathrm{~A}$ cells treated with caspase 3 inhibitor Ac-DEVD-FMK ( $\left.\mathrm{SiHa}^{\mathrm{wt}}+\mathrm{fmk} / \mathrm{C}-33 \mathrm{~A}+\mathrm{fmk}\right)$. Each group was infected with MV-Edm at an MOI of 1, and apoptotic cells were analyzed by Sub G1 Assay and subsequent flow cytometry. Upon infection with the MV-Edm, the number of cells in sub-G1 increased in a time-dependent manner. In both $\mathrm{SiHa}^{\text {wt }}$ and $\mathrm{SiHa}^{\text {sh-cont }}$ groups, MV-Edm induced apoptosis in $\sim 15 \%$ and $\sim 35 \%$ of cells at 48 and 72 hours at an MOI of 1, respectively. However, at the same time points, MV-Edm only induced apoptosis in $\sim 6 \%$ and $\sim 17 \%$ of cells in both $\mathrm{SiHa}^{\text {sh-c3 }}$ and $\mathrm{SiHa}^{\mathrm{wt}}+$ fmk groups
(Figure 3b). The similar results were found in C-33A cell line (Figure S-2c). We further examined some protein expressions that were involved in cellular apoptosis, and found the MV-Edm increased the expressions of cleaved caspase 9, caspase 3 and cleaved PARP but decreasing the protein expression of $\mathrm{Bcl}-2$ in the cells of $\mathrm{SiHa}^{\mathrm{wt}}$ and $\mathrm{SiHa}^{\text {sh-cont }}$ groups, compared to those in $\mathrm{SiHa}^{\text {wt }}$ cells without virus infection, while caspase 8 was not activated. And compared to $\mathrm{SiHa}^{\mathrm{wt}}$ and $\mathrm{SiHa}^{\text {sh-cont }}$ groups, the lower expressions of cleaved caspase 3 and cleaved PARP and higer Bcl-2 expression were obvious higher in cells of $\mathrm{SiHa}^{\text {sh-c3 }}$ and $\mathrm{SiHa}^{\mathrm{wt}}+\mathrm{fmk}$ groups (Figure 3c). The expressions of these key proteins were also determined in the C-33A cell line (Figure S-2b), which was similar with those results in $\mathrm{SiHa}$ cell line.

The caspase 3 activity was significantly increased after 48 and 72 hours of virus infection in $\mathrm{SiHa}^{\mathrm{wt}}$ and $\mathrm{SiHa}^{\text {sh-cont }}$ groups while without any changes in cells of $\mathrm{SiHa}^{\text {sh-3 }}$ and $\mathrm{SiHa}+$ fmk groups (Figure $3 \mathrm{~d}$ ), which was similar with the results of Western Blot. Also, the results were testified in the C-33A cell line (Figure S-2d).

\section{The role of caspase- 3 in $\mathrm{CC}$ cell death induced by $\mathrm{MV}$-Edm replication}

To validate the role of apoptosis induced by caspase 3 in the oncolytic therapy with MV-Edm, the cell
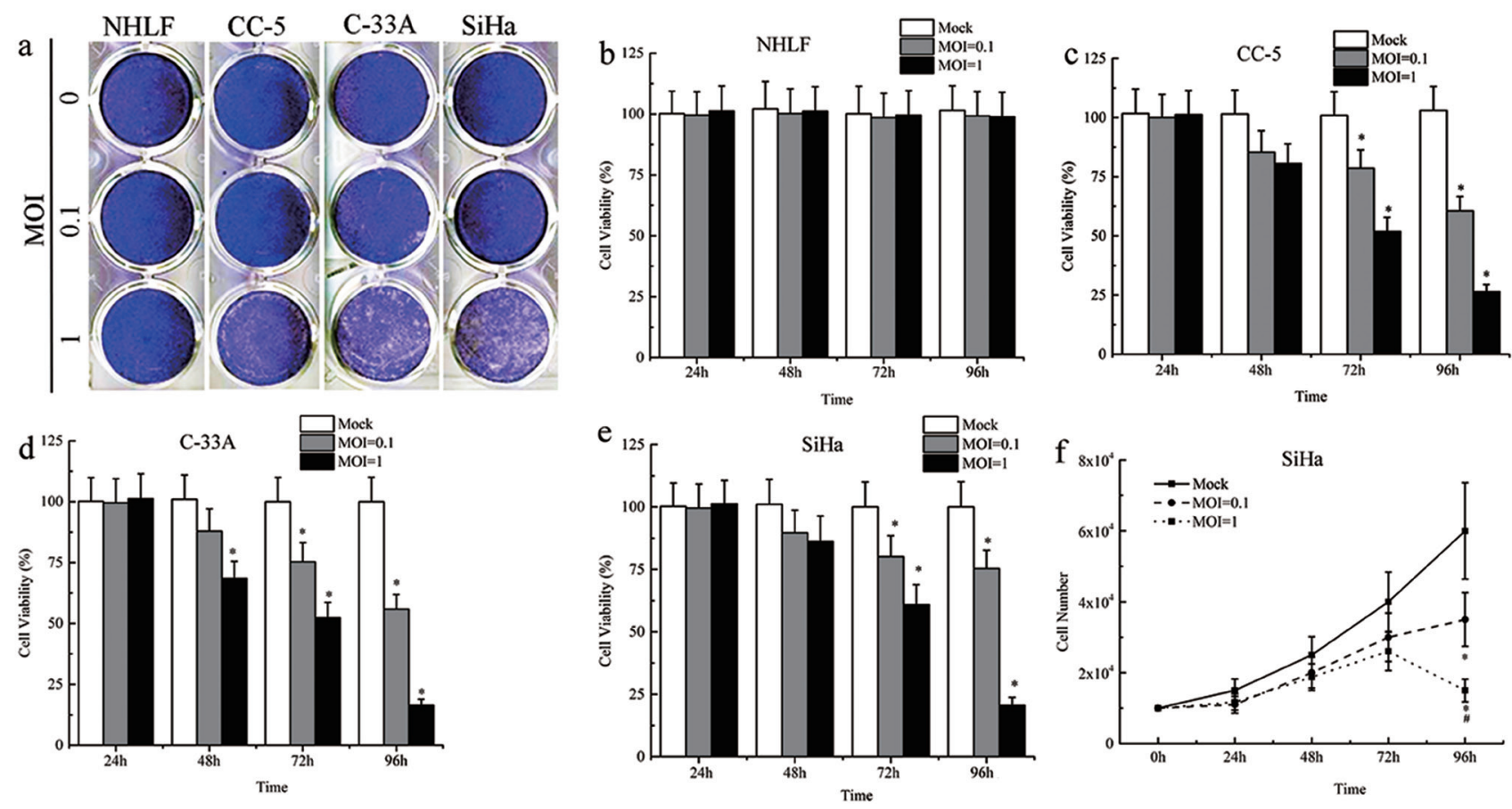

Figure 2: Cytopathic effects and cell death induced by MV-Edm. a. Serial analysis to determine the cytopathic effects (CPEs) of MV-Edm was performed on the human CC cell lines SiHa and C-33A, primary cancer cells CC-5 and normal cell line NHLF. Ninety-six hours after infection at MOIs of 0.1 and 1 , the cells were stained with crystal violet representing viable attached cells. b-e. The time course of cell viability of the human CC cell lines, primary cancer cells and normal cell line after infection with MV-Edm at MOIs of 0.1 and 1 was analyzed by the MTS assay. f. Live Cell counts assay was performed to evaluate the number of cells by Trypan Blue Staining. All data were presented as means $\pm \mathrm{SD}$. *means $P<0.05$ when compared to MOCK group. 
a
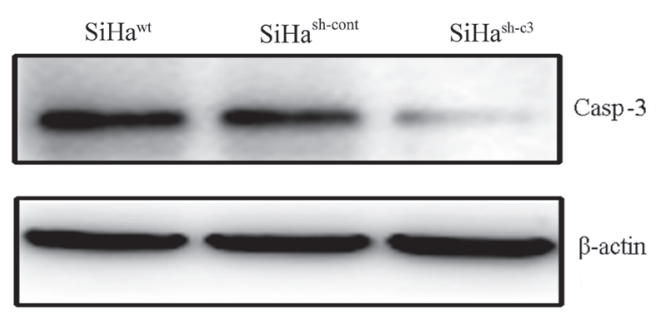

c
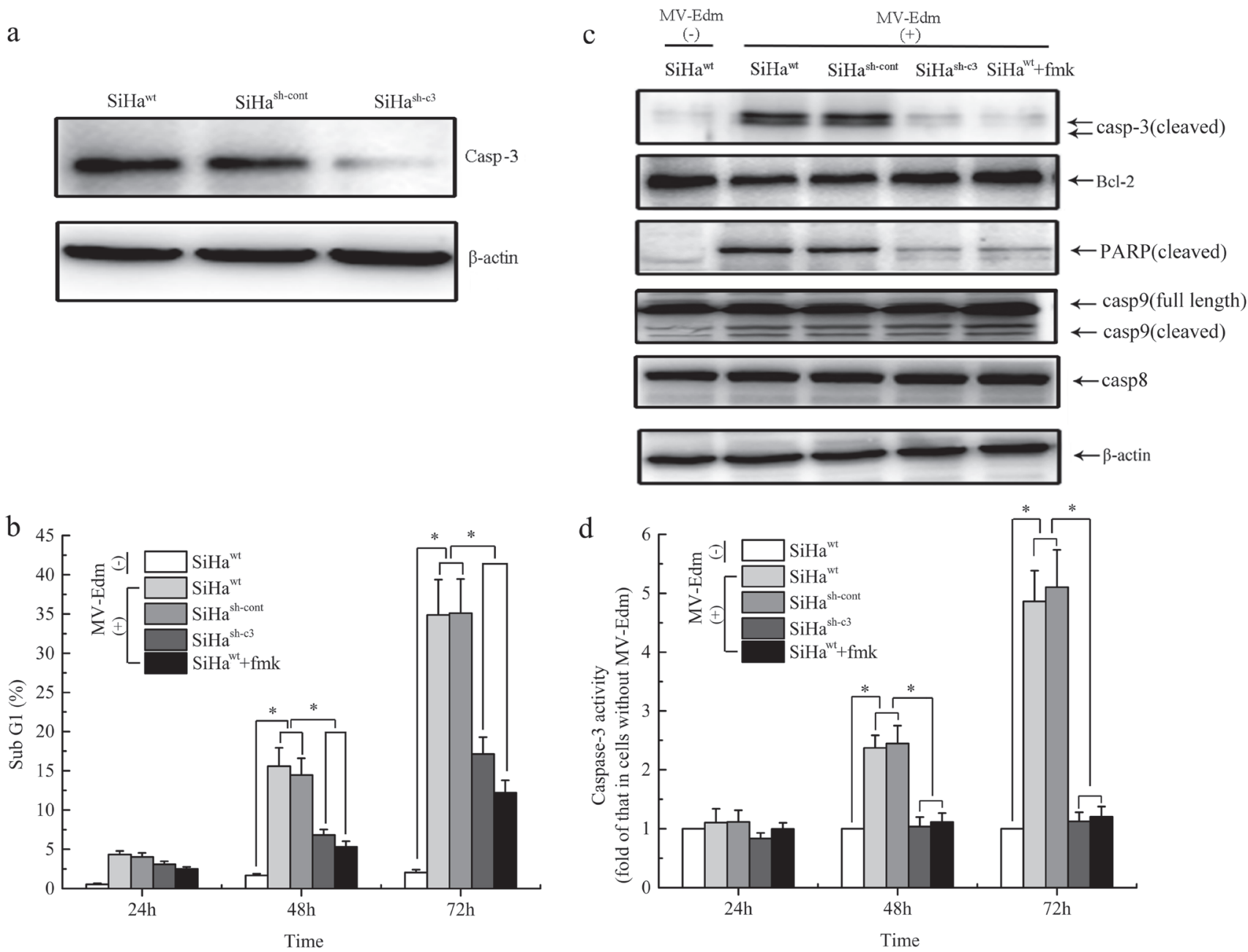

Figure 3: Role of Caspase-3 in the cellular apoptosis induced by MV-Edm infection in vitro. a. SiHa cells were transfected with scramble shRNA or shRNA specific against Caspase-3 (sh-c3), and western blot analysis was performed using the indicated antibodies. b. The percentage of sub-G1 cells was measured by fluorescence-activated cell sorting. c. At $72 \mathrm{~h}$, protein levels of Bcl-2, cleaved caspase-3 and PARP in the infected and uninfected SiHa cells were analyzed with Western Blot. d. At indicated times, the activity of caspase-3 from each group was determined using caspase- 3 activity Kit. Data were presented as means \pm SD. *means $P<0.05$.

viability of each group was assessed with MTS method. The results showed that, after 72 and 96 hours of the virus infection, the cell viability in $\mathrm{SiHa}^{\mathrm{wt}}$ and $\mathrm{SiHa}^{\text {sh-cont }}$ groups was obviously lower than that in $\mathrm{SiHa}^{\mathrm{sh}-\mathrm{c} 3}$ and $\mathrm{SiHa}^{\mathrm{wt}}+\mathrm{fmk}$ groups (Figure 4a). Then we determined the viral titers in cells infected with MV-Edm at an MOI of 1 from 12 to 120 hours with TCID $_{50}$ method. We found that the viral titer in $\mathrm{SiHa}^{\text {sh-cont }}$ cells peaked at $72 \mathrm{~h}$ but for the viral titer in both $\mathrm{SiHa}^{\text {sh-c3 }}$ and $\mathrm{SiHa}^{\mathrm{wt}}+$ fmk groups peaked at $84 \mathrm{~h}$ (Figure 4b). The viral replication was detected with qPCR and the result showed that the intracellular viral mRNA in $\mathrm{SiHa}^{\text {sh-cont }}$ cells was significantly higher than those in $\mathrm{SiHa}^{\text {sh-c } 3}$ and $\mathrm{SiHa}^{\mathrm{wt}}+\mathrm{fmk}$ groups at $24 \mathrm{~h}$ and $48 \mathrm{~h}$ after infection $(P<0.05$, Figure $4 \mathrm{c})$. After analysis on the data above, we found that the cellular apoptosis mediated by caspase 3 was positively correlated to the viral replication in a time dependent manner during the oncolytic process in CC cells (Figure 4d and 4e).
All the experiments have been performed and the corresponding results were confirmed in C-33A cell line (Figure S-3).

\section{Regulation of MV-Edm induced INF- $\alpha$ release and virus production by caspase 3}

We next conducted experiments to confirm the role of caspase 3 in MV-Edm induced INF- $\alpha$ release and virus production. INF- $\alpha$ levels in $\mathrm{SiHa}^{\text {sh-cont }}, \mathrm{SiHa}^{\text {sh-c3 }}$ and $\mathrm{SiHa}^{\mathrm{wt}}+$ fmk groups were determined with ELISA Kit at 48 hours after the viral infection $(\mathrm{MOI}=1)$, respectively. We found that Caspase- 3 inhibited INF- $\alpha$ release from infected cells (Figure 5a). To investigate whether IFN- $\alpha$ could prevent the virus replication through caspase 3 , the cells were co-treated with Human IFN- $\alpha$ (100 IU/ml), and infected by MV-Edm at an MOI of 1 . The intracellular titers, as well as the cleaved caspase 3 , at different times 

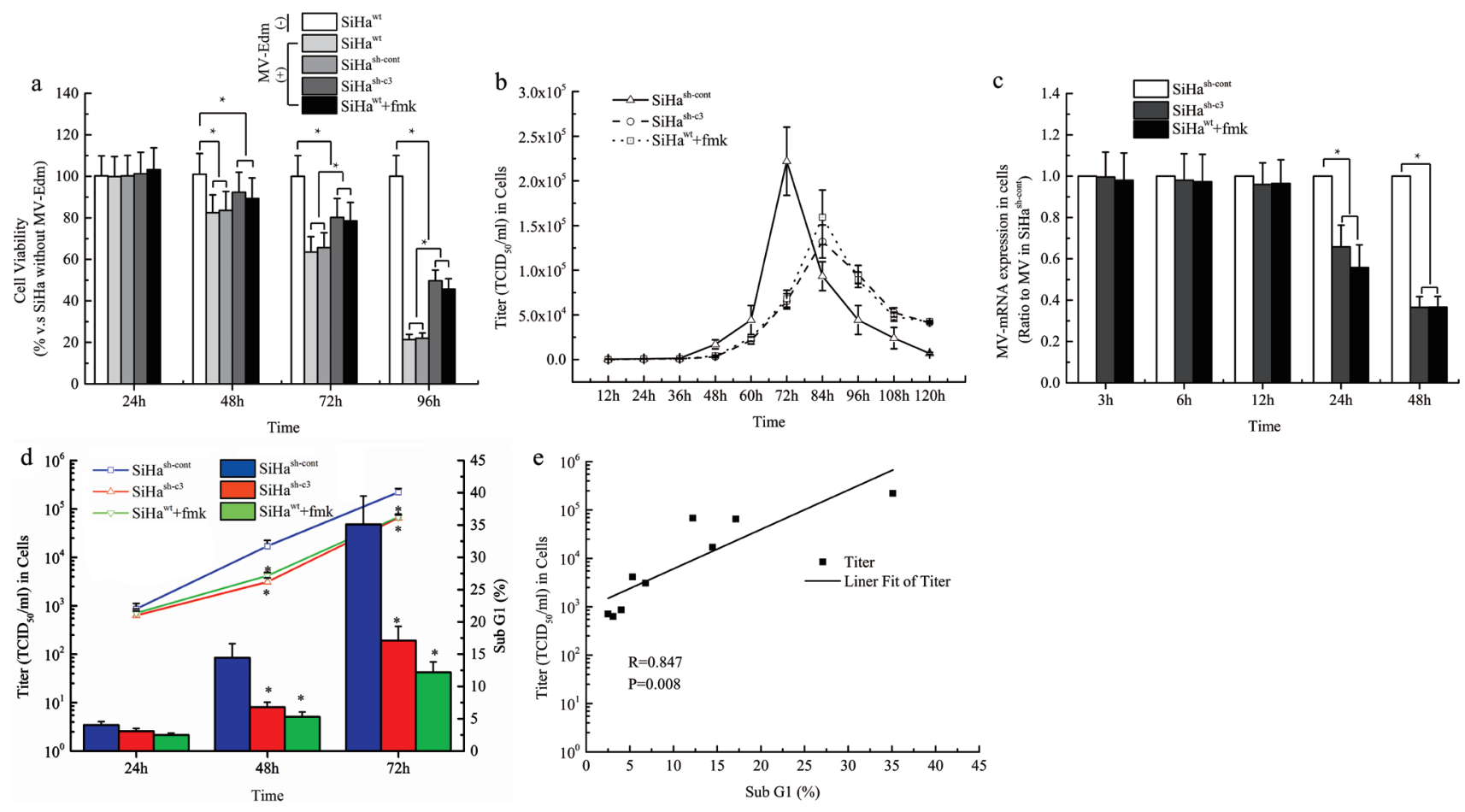

Figure 4: The role of Caspase-3 in the cell death induced by MV-Edm and the MV-Edm replication. a. At indicated times, the cell viability of each group was assessed with MTS assay. b. The intracellular virus replication of $\mathrm{SiHa}^{\mathrm{H}}$ cells, expressed as TCID $/ \mathrm{ml}$, was determined at different times after infection at an MOI of 1. c. The viral mRNA levels were measured using real-time PCR. Each value is normalized to that in $\mathrm{SiHa}$ cells transfected with empty vector $\left(\mathrm{SiHa}^{\text {sh-cont }}\right)$, which was set a ratio $=1$, and represented with mean $\pm \mathrm{SD}$. d. The comparisons of virus production and cellular apoptosis induced by MV-Edm in SiHa cells from each group. e. Liner Fit curve between cellular apoptosis and virus production. *means $P<0.05$.

after infection were determined respectively. Human IFN- $\alpha$ inhibited the viral replication and caspase 3 cleavage at 48 hours (Figure $5 b$ ).

The same experiments were carried out in C-33A cell line and the results were given in the Figure S-4.

\section{Deficiency in caspase 3 correlated with tumor response to oncolytic therapy in mice}

To validate the role of caspase 3 mediated apoptosis on the oncolytic effects of MV-Edm in vivo, $\mathrm{SiHa}^{\text {wt }}, \mathrm{SiHa}^{\text {sh-cont }}$, and $\mathrm{SiHa}^{\text {sh-c } 3}$ cells were injected s.c. into the right (or left) flank of BALB/c-nu/nu mice. All animals were examined daily for the appearance of palpable tumors. When the tumors were more than $5 \mathrm{~mm}$ in diameter at the time of measurement, MV-Edm was given intratumorally to nude mice bearing established subcutaneous xenografts $(n=10)$. Intratumoral administration of MV-Edm (10 doses of $1.0 \times 10^{6} \mathrm{TCID}_{50} /$ dose) effectively suppressed the $\mathrm{SiHa}^{\text {wt }}$ and $\mathrm{SiHa}^{\text {sh-cont }}$ xenografts than $\mathrm{SiHa}^{\text {sh-c3 }}$ xenografts (Figure 6a). At 150 days after injection, the survival rate was significantly improved in the $\mathrm{SiHa}^{\text {wt }}$ and $\mathrm{SiHa}^{\text {sh-cont }}$ groups (30-40\%), compared to the $\mathrm{SiHa}^{\text {sh-c3 }}$ group (0\%) (Figure $6 \mathrm{~b}$ ). The xenografts infected with MV-Edm had
mRNA expression of the M gene of MV-Edm and the results showed that MV-Edm replicated in the $\mathrm{SiHa}^{\text {wt }}$ and $\mathrm{SiHa}^{\text {sh-cont }}$ xenografts, but less effectively in $\mathrm{SiHa}^{\text {sh-c3 }}$ group, at 5,9 and 13 days after the viral injection $(P<0.05)$ (Figure 6c). And the apoptosis in the xenografts of each group was confirmed by TUNEL assay on the $13^{\text {rd }}$ day of virus treatment (Figure 6d).

\section{DISCUSSION}

Oncolytic virotherapy is an emerging treatment modality that uses replication-competent viruses to destroy cancers specifically, which are currently being explored in the clinic [30-35]. And oncolytic viruses are genetically programmed to replicate within cancer cells and directly induce toxic effect via cell lysis or apoptosis.

In clinical trials, it was reported that liveattenuated MV strain has been used as an option of treatment for patients with stage I or II cancer [36]. Although MV treatment was tested in many kinds of tumor cells, MV has not been reported in the treatment of CC as a common virus system for oncolytic therapy. And besides this, that oncolytic therapy compounds 

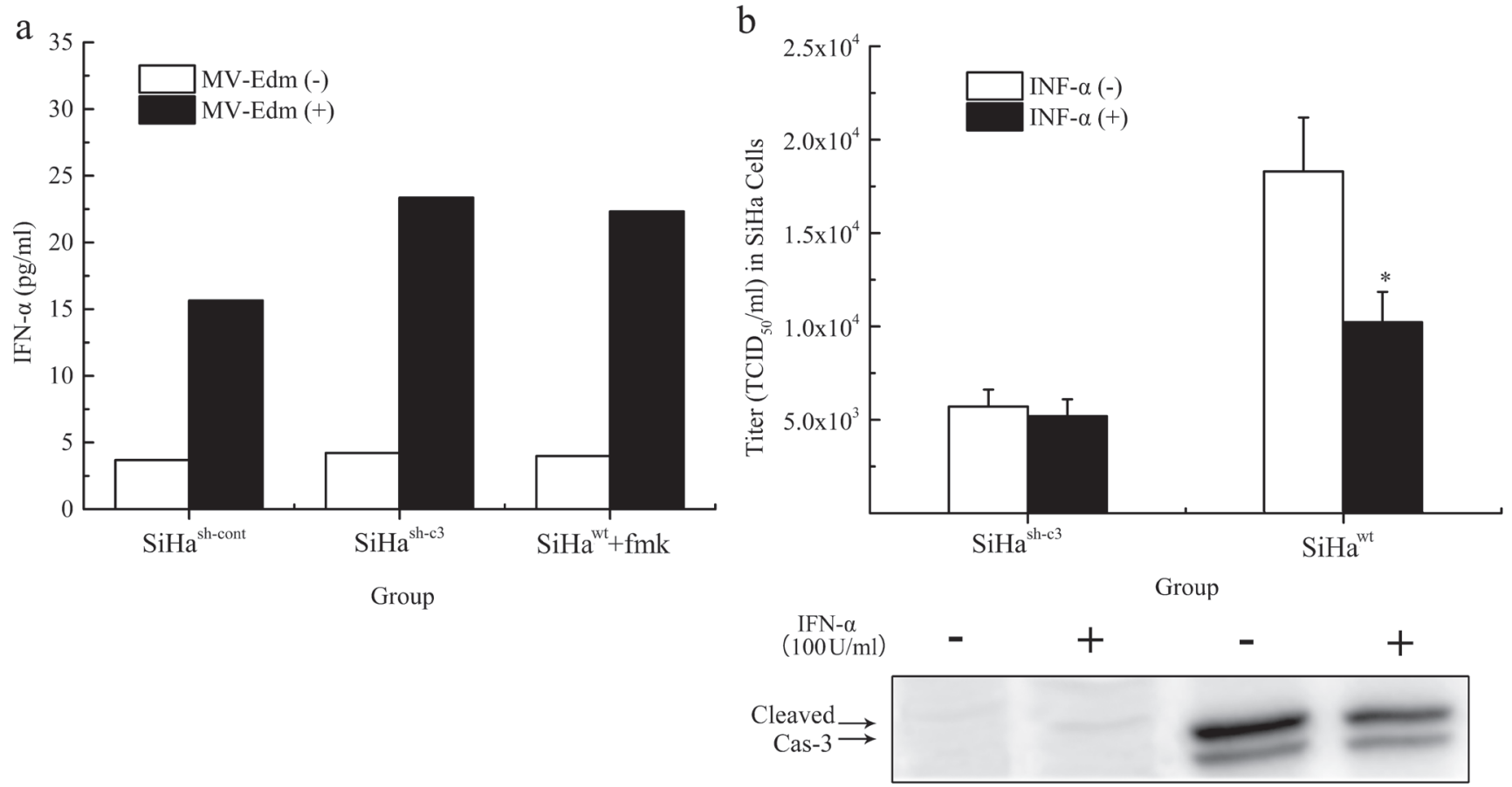

Figure 5: Regulation of MV-Edm induced INF- $\alpha$ release and virus production by caspase 3. a. After 48-hour infection, the production of IFN- $\alpha$ in SiHa cells was determined using human IFN- $\alpha$ enzyme-linked immunosorbent assay kit. The IFN- $\alpha$ data from samples were collected together in a single experiment. b. The intracellular virus replication and the expression of cleaved caspase 3 in $\mathrm{SiHa}$ cells co-treated with or without INF- $\alpha$ were compared at different 48 hours after infection at an MOI of 1 . The data were presented as means \pm SD. *means $P<0.05$.

with cellular apoptosis is not well elucidated at present. Here, for the first time, we described cellular apoptosis induced by infection of MV-Edm was mainly mediated by caspase 3 and elucidated the role of the caspase 3 mediated apoptosis in the process of oncolytic virotherapy with MV-Edm, besides confirming the potent antitumor activity of MV-Edm against human CC cells in vitro and in vivo.

It has been reported that the effectiveness of MV-Edm-mediated oncolysis is dependent upon the expression of the cellular attachment receptor CD46 which is more frequently over-expressed in human cancer cells than in normal cells. Our data demonstrated that CD46 was overexpressed in human CC cell lines as well as primarily cultured human $\mathrm{CC}$ cells with 11 -fold higher than in the normal human NHLF cell line. That made it possible for the MV-Edm to infect human CC cells by preferentially binding to CD46.

Compared to cancer cells, MV-Edm induces minimal CPEs in normal human cell line, suggesting that $\mathrm{CC}$ cancer cells were suitable targets for MV-Edm infection. In our experiments, we found that MV-Edm at an MOI of 1 killed the human CC cells more effectively, which was validated by cell counting, while virus at an MOI of 0.1 only inhibited the cell growth. We further determined the replication ability of MV-Edm in the
$\mathrm{CC}$ cells using the Tissue Culture Infectious Dose 50\% $\left(\mathrm{TCID}_{50}\right)$ Assay every 12 hour for 120 hours. We found that MV-Edm strains had a strong ability to replicate in $\mathrm{CC}$ cells in a time-dependent manner. The results of cell counting and viral titer changes suggested that the cell growth was inhibited at the early-stage of infection CC cells, then the cells was killed and lysed at the late-stage of viral infection. At the same time, the viral replication was also proved to be time-dependent through detection of the viral M gene [14]. Therefore, we esteemed that the oncolysis in CC cells was induced by MV-Edm mRNA transcription followed by abundant intracellular virus production which accelerated cancer cells lysis and led to cellular necrosis after viral infection.

Apoptosis is often called programmed cell death. Now, a large number of studies have shown that chemotherapy and radiotherapy can induce apoptosis in tumor cells [37, 38]. However, apoptosis is a double-edged sword. It is reported that drug-induced apoptosis can enhance oncolytic effect of MV-Edm in glioblastoma [39], but apoptosis via activation of caspase-3 during radiotherapy can mediate stimulation of tumor repopulation [40]. However, the role of caspase 3 in the oncolytic therapy with MV-Edm remains unclear. Our previous data have shown that our engineered MV had the ability to rapidly induce apoptosis in human renal 
a
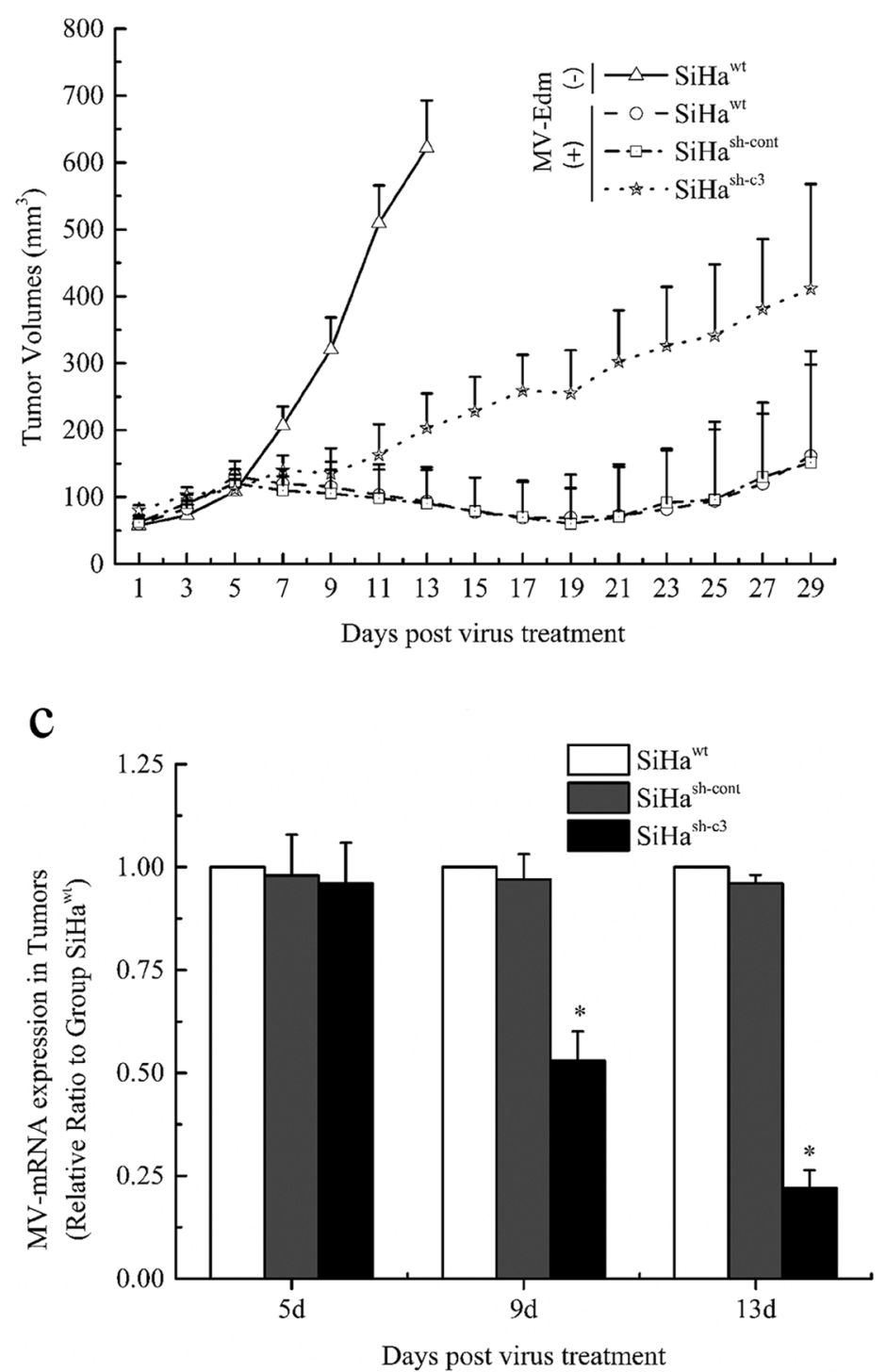

b
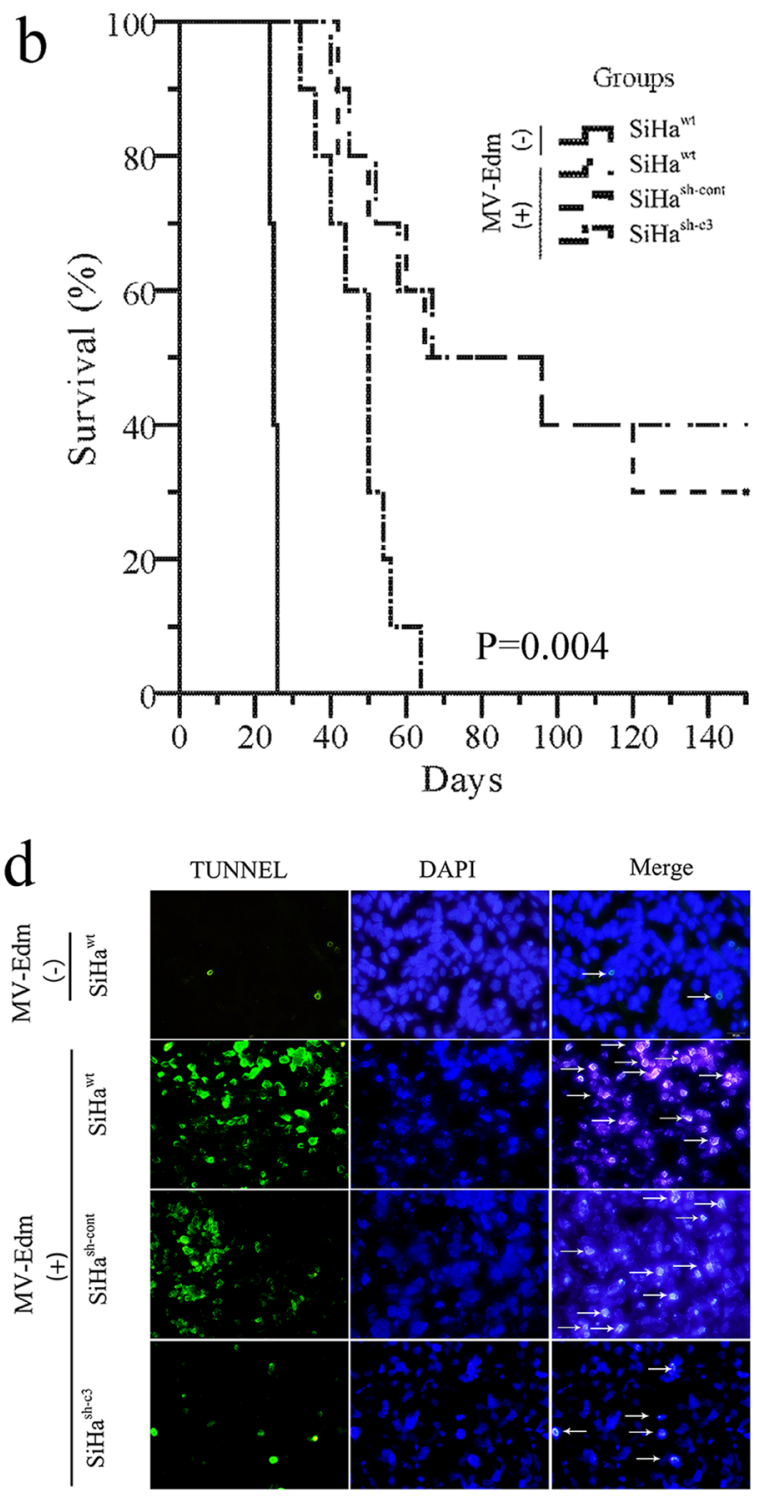

Figure 6: Deficiency in caspase 3 correlated with tumor response to oncolytic therapy in mice. a. The increase in tumor volume after initiation of MV-Edm therapy. The data were presented as means \pm SD. b. Kaplan-Meier survival curves of mice from different groups. c. The replication of MV-Edm in the xenografs was evaluated with qPCR. The data were presented as means \pm SD. d. Morphological changes of apoptosis in vivo of SiHa cancer model. White arrows indicate apoptotic cells (TUNEL stain, $\times 200)$. *means $P<0.05$.

cancer cells [14]. In this study, we found that MV-Edm also effectively induced the apoptosis in CC cells in a time- and caspase-3 dependent manner. The cell viability of caspase 3 deficient cells was obviously higher than that in wild-type cells after viral infection, and knockdown of caspase 3 attenuated the ability of MV-Edm to induce the apoptosis and reduce viral replication capacity in CC cells, suggesting that caspase 3 played a vital role during the process of the oncolysis.

Interferon $\alpha(\mathrm{IFN}-\alpha)$ is an important factor in the innate immunity and is essential for the response to measles virus [26, 41]. It acts on neighboring cells that are not apoptotic yet. In paracrine manner, in these neighboring cells, IFN-a decrease viral replication [42]. In most cases, to combat the cellular innate immune response, many viruses encode antagonistic proteins that block some steps of the IFN- $\alpha$ antiviral response. We proved that the cellular apoptosis mediated by caspase 3 inhibited the inner IFN $\alpha$ release after 48 hours of the infection, which resulted in the loss of natural barriers to virus replication in the cells. Our further findings showed that IFN $\alpha$ at a relatively low concentration could not 
effectively suppress the viral replication in caspase 3 deficient CC cells, while it functioned effectively in the wild-type cells. And the expression of cleaved caspase 3 was also decreased in the IFN $\alpha$ treated cells after the viral infection, suggesting that IFN $\alpha$ not only inhibited the virus replication directly but also functioned through the down-regulation of cleaved caspase 3 in CC cells, which has been proved by the results of virus titer with TCID $_{50}$ method. In animal experiments, we found that caspase 3 mediated apoptosis enhanced the oncolytic effects of MV-Edm in CC tumor, which coincided with the results from those results in vitro.

In conclusion, MV-Edm has potent therapeutic efficacy in human CC both in vivo and in vitro. During the process of MV-Edm infection, MV-Edm could escape from the host immune surveillance, at least partially, through activing caspase 3 to inhibit IFN $\alpha$ release in $\mathrm{CC}$ cells. We believe caspase 3 can be a new target to enhance the oncolytic effects of MV-Edm in CC cells. That whether oncolytic therapy with MV-Edm can be enhanced via chemoradiation mediated apoptosis is our research focus in the future.

\section{MATERIALS AND METHODS}

\section{Cell culture}

The human CC cell lines SiHa and C-33A (ATCC, Manassas, VA) were maintained in Eagle's Minimum Essential Medium supplemented with $10 \%$ heatinactivated fetal bovine serum (Bioserum, Japan). The normal human lung fibroblast cell line NHLF (Clonetics, San Diego, CA) were maintained in Dulbecco's modified Eagle's medium supplemented with 10\% heatinactivated fetal bovine serum (Bioserum, Japan). Vero cells were used to produce measles virus and maintained in Dulbecco's modified Eagle's medium supplemented with $5 \%$ heat-inactivated fetal bovine serum (Bioserum, Japan). All media used in this study contained $100 \mathrm{U} / \mathrm{ml}$ of penicillin - streptomycin. Primary human CC tissues were established using surgical specimens immediately after resection from the First Affiliated Hospital of China Medical University after institutional review board approval and informed patient consent. Briefly, tissues were treated with collagenase (GIBCO, Invitrogen, Carlsbad, CA) at $37^{\circ} \mathrm{C}$ for 2 hours on a shaker, and then filtered through a nylon mesh (100- $\mu$ m diameter) to obtain single cell suspensions. Harvested cells were cultured in Minimum Essential Medium- $\alpha$ medium (GIBCO, Invitrogen) supplemented with $10 \%$ fetal bovine serum (Hyclone, Logan, UT) and $4 \mu \mathrm{g} / \mathrm{ml}$ of Gentamicin Reagent Solution (GIBCO, Invitrogen). All cell lines used in this study were cultured in a humidified atmosphere containing $5 \% \mathrm{CO}_{2}$ at $37^{\circ} \mathrm{C}$.

\section{Flow cytometry}

CD46 expression and the apoptosis of cells were determined by flow cytometry. To measure CD46 expression, the cells were harvested and incubated with a fluorescein isothiocyanate-labeled monoclonal mouse antihuman CD46 or control antibodies (BD Biosciences, Pharmingen) for 0.5 hour on ice. Then cells were washed twice with cold PBS and $1 \times 10^{4}$ cells per sample were analyzed using a FACScan (BD Biosciences, San Jose, $\mathrm{CA})$. For sub-G1 analysis, SiHa cells were seeded in 6-well plates and infected with MV-Edm at an MOI of 1. All the cells were harvested at 24, 48, and 72 hours after infection and fixed in ice-cold $70 \%$ ethanol for at least 1 hour. Then the cells were rinsed twice with PBS and incubated for 30 minutes at room temperature in $1 \mathrm{ml}$ PBS containing $50 \mu \mathrm{g}$ propidium iodide (Sigma-Aldrich, St Louis, MO), 0.1\% Triton X-100, 1 mmol/1 EDTA, and $0.5 \mathrm{mg}$ RNaseA. The stained cells were subjected to flow cytometric analysis with a FACScan (BD Biosciences, San Jose, CA). Fragmented, apoptotic nuclei were recognized by their sub-G1 DNA content. The proportion of cells in sub-G1 phase was determined for each group.

\section{Evaluation of CPEs in vitro}

SiHa, C-33A, CC-5 (primary cultured human CC cells), and NHLF cells were cultured in 24-well plates at a density of $2 \times 10^{4}$ cells/well. The cells were infected with MV-Edm at an MOI of 1 or 0.1 in $0.2 \mathrm{ml}$ of Opti-MEM I (GIBCO, Invitrogen) for 2 hours. The virus suspension was removed, and $1 \mathrm{ml}$ of fresh medium was added to each well. At 120 hours after infection, the cells were gently washed twice with PBS, and the remaining cells were fixed with $0.5 \%$ glutaraldehyde in PBS for 15 minutes. Then, cells were washed with PBS and stained with $0.1 \%$ crystal violet solubilized in $2 \%$ ethanol-distilled water. The stained product was subsequently washed twice with distilled water, air-dried, and then photographed.

\section{Cell counting with trypan blue staining}

To determine cell viability and viable cell yield with the Trypan Blue Exclusion Method, follow the directions below. SiHa cells were cultured in 24-well plates at a density of $2 \times 10^{4}$ cells/well and infected with MV-Edm at an MOI of 1 . After $24 \mathrm{~h}, 48 \mathrm{~h}, 72 \mathrm{~h}$ and $96 \mathrm{~h}$, prepare the cells suspension in Hanks' Balanced Salts Solution (HBSS) and then transfer $0.5 \mathrm{ml}$ of $0.4 \%$ Trypan Blue solution $(\mathrm{w} / \mathrm{v})$ to a test tube. Add $0.3 \mathrm{ml}$ of HBSS and $0.2 \mathrm{ml}$ of the cell suspension (dilution factor $=5$ ) and mix thoroughly. Allow to stand for 5 to 15 minutes. 


\section{Stable shRNA mediated repression of caspase 3 in $\mathrm{SiHa}$ cells}

The expression of human caspase 3 in $\mathrm{SiHa}$ and C-33A cells was silenced by shRNA interference. The shRNA against caspase 3 (NM_004346) system was designed and purchased from GeneChem Corporation (Shanghai, China). An adopted nonsilencing control shRNA sequence that was not complementary to any human gene was used as a control shRNA. The sequences of these shRNA is: 5'- CCGGGCGAATCAATGGACTCTGGAA CTCGAG TTCCAGAGTCCATTGATTCGC TTTTTG - 3' (in bold red are the sense and antisense targeting sequences and in underlined blue is loop sequence). SiHa and C-33A cells were transfected with Lipofectamine 2000 reagent (Invitrogen) as instructed by the supplier and subjected to western blot to test the expression level of caspase 3 in the transfected cells.

\section{Western blot analysis}

The cells were scraped in cold PBS and lysed in buffer containing 50mM Tris $\mathrm{pH} 7.8,150 \mathrm{mM} \mathrm{NaCl}$, $5 \mathrm{mM}$ EDTA, $1 \mathrm{mM} \mathrm{Na} \mathrm{VO}_{4}, 10 \mathrm{mM} \mathrm{NaF}, 10 \mathrm{mM}$ NaPyrophosphate, 1\% NP-40 and 1/7 of Protease cocktail inhibitors (Roche). Western blotting was done using standard $10 \%$ SDS-PAGE gel, loading $40 \mu \mathrm{g}$ of protein per lane, with detection by enhanced chemiluminescence. For apoptosis assessment, antibodies against caspase-3 (dilution 1:1000, Cell Signaling Technology), Bcl-2 and Bax (dilution 1:1000, Cell Signaling Technology) were used. For loading control we used $\beta$-actin (dilution 1:5000, Cell Signaling Technology). All the primary antibodies were incubated for 2 hours at RT. The immunereactivity of the blots was visualized using an enhanced chemiluminescence detection system (Amersham, Piscataway, NJ).

\section{Cell proliferation assay}

The Cell-Titer 96 Aqueous Non-Radioactive Cell Proliferation Assay (Promega, Madison, WI) was used in this study. $\mathrm{SiHa}, \mathrm{C}-33 \mathrm{~A}, \mathrm{CC}-5$, and NHLF cells were seeded in 96-well plates at a density of $1 \times 10^{4}$ cells/well. Twelve hours after seeding, the cells were infected with MV-Edm at an MOI of 1 for different time intervals and then incubated with $20 \mu \mathrm{l}$ of MTS reagent for 4 hours at $37^{\circ} \mathrm{C}$. The absorbance at $490 \mathrm{~nm}$ was recorded using an ELISA plate reader.

\section{Real time RT-PCR}

The cells or the xenograft tissues were collected at different time intervals. Total RNA was extracted with miRNeasy/Protect Mini Kit (QIAGEN, Shanghai, China) according to manufacturer's instructions. Primers for
M gene were designed mainly using Primer Premier 6 software. The following primers were used for qRT-PCR by SYBR Green method: 5'-GTTATGGACTCGCTATCTGT-3' (Sense primer) and 5'-CGGTGCTTGATGTTCTGA-3' (Antisense primer). Real-time PCR was performed on ABI 7500 PCR Instrument (ABI, Foster City, CA, USA) with a SYBR Green Real-time PCR Master Mix Kit (Toyobo, Tokyo, Japan). The relative mRNA levels of MV-Edm in cells were calculated using the $2^{-B B C T}$ method with the endogenous $\beta$-actin mRNA as control.

\section{Assessment of MV replication in a human CC cells}

The human $\mathrm{CC}$ cell lines were seeded in 6-well plates at a density of $2.0 \times 10^{4}$ cells/ well. Twelve hours after plating, the cells were infected with MV-Edm at an MOI of 1 in Opti-MEM I. The cells and supernatants were collected at different time intervals. The viruses were released by two cycles of freezing and thawing. The viral titers in the cells and supernatants were determined by titrating the $\mathrm{TCID}_{50}$ on Vero cells.

\section{In vivo xenograft experiments}

Athymic female nude mice (BALB/c-nu/nu, 4 weeks old, and weighing 20g; Vital River Laboratories, Inc., Beijing, China) were injected s.c. into the right (or left) flank with $2 \times 10^{6} \mathrm{SiHa}$ cells in $100 \mu \mathrm{l}$ PBS. After tumors were established, nude mice with $\mathrm{SiHa}$ tumors were randomly assigned to two groups with 10 mice in each group. MV-Edm group: the mice were injected with treated with MV-Edm $\left(2 \times 10^{5}\right.$ TCID50 in $50 \mu$ OptiMEM I) every 2 days, total 10 times; MOCK group: the mice were treated with Opti-MEM I containing no virus, correspondingly. Tumors were measured every 2 days and tumor sizes were calculated by using the function $\left[a \times 0.5 b^{2}\right]$, where $a$ and $b$ are the length and width of tumors, respectively.

Mice were killed if they lost $>20 \%$ of their body weight or the tumor diameter exceeded $1.0 \mathrm{~cm}$. All mouse experiments were approved by the Committee of the Ethics on Animal Experiments in the Faculty of Medicine, China Medical University and carried out following the Guidelines for Animal Experiments in the Faculty of Medicine, China Medical University and The Law and Notification of the Government.

\section{In situ cell death (apoptosis) detection by TUNEL labeling}

In situ hybridization for terminal deoxynucleotidyl transferase-mediated nick end labeling (TUNEL) was performed on paraffin sections as recommended by the manufacturer (Merck Millipore, Kilsyth, Vic, Australia). Apoptotic cells were identified by 
double labelling using TUNEL. And sections were counterstained with DAPI. These glass coverslips were then visualized under a fluorescence microscope (OLYMPUS TH4-200).

\section{Statistical analysis}

Each experiment was repeated three different times, and data are presented as means $\pm \mathrm{SD}$. The data were analyzed by a one-way analysis of variance (ANOVA) or unpaired Student's $t$ test with Bonferroni correction. Statistical analysis of tumor volumes before and after infection among the groups was performed using the Kruskal-Wallis test. Wilcoxon Rank-Sum test was used to determine two-group tumor volume comparisons. To assess survival, Kaplan-Meir curves were generated. The survival of mice in the different treatment groups was compared using the log-rank test. All analysis was performed using SPSS 13.0 software (SPSS, Chicago, IL). A $p$ value of $<0.05$ was considered statistically significant.

\section{ACKNOWLEDGMENTS}

This work was supported by National Natural Science Foundation of China (81301838, 81271292), Funding of Scientific \& Technological Projects for Abroad Students of Ministry of Human Resources and Social Security of China (2011LX001). China Postdoctoral Science Foundation (2012M520655). Liaoning Province Doctor Startup Fund (20111110). Key Scientific and Technological Project of Shenyang (F13-220-9-44).

\section{CONFLICTS OF INTEREST}

We declare that there are no competing financial interests in relation to the work described.

\section{REFERENCES}

1. Suh DH, Kim JW, Kang S, Kim HJ, Lee KH. Major clinical research advances in gynecologic cancer in 2013. Journal of gynecologic oncology. 2014; 25:236-248.

2. Seol HJ, Ki KD, Lee JM. Epidemiologic characteristics of cervical cancer in Korean women. Journal of gynecologic oncology. 2014; 25:70-74.

3. Jackson JD, McMorris AM, Roth JC, Coleman JM, Whitley RJ, Gillespie GY, Carroll SL, Markert JM, Cassady KA. Assessment of oncolytic HSV efficacy following increased entry-receptor expression in malignant peripheral nerve sheath tumor cell lines. Gene therapy. 2014.

4. Ishihara M, Seo N, Mitsui J, Muraoka D, Tanaka M, Mineno J, Ikeda H, Shiku H. Systemic CD8+ T CellMediated Tumoricidal Effects by Intratumoral Treatment of Oncolytic Herpes Simplex Virus with the Agonistic Monoclonal Antibody for Murine Glucocorticoid-Induced Tumor Necrosis Factor Receptor. PloS one. 2014; 9:e104669.

5. Meng G, Xia M, Wang D, Chen A, Wang Y, Wang H, $\mathrm{Yu}$ D, Wei J. Mitophagy promotes replication of oncolytic Newcastle disease virus by blocking intrinsic apoptosis in lung cancer cells. Oncotarget. 2014; 5:6365-6374.

6. Bell J. Oncolytic viruses: immune or cytolytic therapy? Molecular therapy : the journal of the American Society of Gene Therapy. 2014; 22:1231-1232.

7. Gholami S, Chen CH, Gao S, Lou E, Fujisawa S, Carson J, Nnoli JE, Chou TC, Bromberg J, Fong Y. Role of MAPK in oncolytic herpes viral therapy in triple-negative breast cancer. Cancer gene therapy. 2014; 21:283-289.

8. Thorne AH, Meisen WH, Russell L, Yoo JY, Bolyard CM, Lathia JD, Rich J, Puduvalli VK, Mao H, Yu J, Caligiuri MA, Tridandapani S, Kaur B. Role of Cysteinerich 61 Protein (CCN1) in Macrophage-mediated Oncolytic Herpes Simplex Virus Clearance. Molecular therapy : the journal of the American Society of Gene Therapy. 2014.

9. Heinzerling L, Kunzi V, Oberholzer PA, Kundig T, Naim H, Dummer R. Oncolytic measles virus in cutaneous T-cell lymphomas mounts antitumor immune responses in vivo and targets interferon-resistant tumor cells. Blood. 2005; 106:2287-2294.

10. Galanis E, Hartmann LC, Cliby WA, Long HJ, Peethambaram PP, Barrette BA, Kaur JS, Haluska PJ Jr., Aderca I, Zollman PJ, Sloan JA, Keeney G, Atherton PJ, Podratz KC, Dowdy SC, Stanhope CR, et al. Phase I trial of intraperitoneal administration of an oncolytic measles virus strain engineered to express carcinoembryonic antigen for recurrent ovarian cancer. Cancer research. 2010; 70:875-882.

11. Peng KW, TenEyck CJ, Galanis E, Kalli KR, Hartmann LC, Russell SJ. Intraperitoneal therapy of ovarian cancer using an engineered measles virus. Cancer research. 2002; 62:4656-4662.

12. Vidal L, Pandha HS, Yap TA, White CL, Twigger K, Vile RG, Melcher A, Coffey M, Harrington KJ, DeBono JS. A phase I study of intravenous oncolytic reovirus type 3 Dearing in patients with advanced cancer. Clinical cancer research : an official journal of the American Association for Cancer Research. 2008; 14:7127-7137.

13. Zhang SC, Wang WL, Cai WS, Jiang KL, Yuan ZW. Engineered measles virus Edmonston strain used as a novel oncolytic viral system against human hepatoblastoma. BMC cancer. 2012; 12:427.

14. Meng X, Nakamura T, Okazaki T, Inoue H, Takahashi A, Miyamoto S, Sakaguchi G, Eto M, Naito S, Takeda M, Yanagi Y, Tani K. Enhanced antitumor effects of an engineered measles virus Edmonston strain expressing the wild-type N, P, L genes on human renal cell carcinoma. 
Molecular therapy : the journal of the American Society of Gene Therapy. 2010; 18:544-551.

15. Reddi HV, Madde P, McDonough SJ, Trujillo MA, Morris JC 3rd, Myers RM, Peng KW, Russell SJ, McIver B, Eberhardt NL. Preclinical efficacy of the oncolytic measles virus expressing the sodium iodide symporter in iodine nonavid anaplastic thyroid cancer: a novel therapeutic agent allowing noninvasive imaging and radioiodine therapy. Cancer gene therapy. 2012; 19:659-665.

16. Msaouel P, Iankov ID, Allen C, Aderca I, Federspiel MJ, Tindall DJ, Morris JC, Koutsilieris M, Russell SJ, Galanis E. Noninvasive imaging and radiovirotherapy of prostate cancer using an oncolytic measles virus expressing the sodium iodide symporter. Molecular therapy : the journal of the American Society of Gene Therapy. 2009; 17:2041-2048.

17. Msaouel P, Iankov ID, Allen C, Morris JC, von Messling V, Cattaneo R, Koutsilieris M, Russell SJ, Galanis E. Engineered measles virus as a novel oncolytic therapy against prostate cancer. The Prostate. 2009; 69:82-91.

18. Wei J, Wahl J, Nakamura T, Stiller D, Mertens T, Debatin KM, Beltinger C. Targeted release of oncolytic measles virus by blood outgrowth endothelial cells in situ inhibits orthotopic gliomas. Gene therapy. 2007; 14:1573-1586.

19. Blechacz B, Splinter PL, Greiner S, Myers R, Peng KW, Federspiel MJ, Russell SJ, LaRusso NF. Engineered measles virus as a novel oncolytic viral therapy system for hepatocellular carcinoma. Hepatology. 2006; 44:1465-1477.

20. Haralambieva I, Iankov I, Hasegawa K, Harvey M, Russell SJ, Peng KW. Engineering oncolytic measles virus to circumvent the intracellular innate immune response. Molecular therapy : the journal of the American Society of Gene Therapy. 2007; 15:588-597.

21. Dorig RE, Marcil A, Chopra A, Richardson CD. The human CD46 molecule is a receptor for measles virus (Edmonston strain). Cell. 1993; 75:295-305.

22. Naniche D, Varior-Krishnan G, Cervoni F, Wild TF, Rossi B, Rabourdin-Combe C, Gerlier D. Human membrane cofactor protein (CD46) acts as a cellular receptor for measles virus. Journal of virology. 1993; 67:6025-6032.

23. Tatsuo H, Ono N, Tanaka K, Yanagi Y. SLAM (CDw150) is a cellular receptor for measles virus. Nature. 2000; 406:893-897.

24. Ohno S, Ono N, Takeda M, Takeuchi K, Yanagi Y. Dissection of measles virus $\mathrm{V}$ protein in relation to its ability to block alpha/beta interferon signal transduction. The Journal of general virology. 2004; 85:2991-2999.

25. Shingai M, Ebihara T, Begum NA, Kato A, Honma T, Matsumoto K, Saito H, Ogura H, Matsumoto M, Seya T. Differential type I IFN-inducing abilities of wild-type versus vaccine strains of measles virus. Journal of immunology. 2007; 179:6123-6133.
26. Naniche D, Yeh A, Eto D, Manchester M, Friedman RM, Oldstone MB. Evasion of host defenses by measles virus: wild-type measles virus infection interferes with induction of Alpha/Beta interferon production. Journal of virology. 2000; 74:7478-7484.

27. McDonald CJ, Erlichman $\mathrm{C}$, Ingle $\mathrm{JN}$, Rosales GA, Allen C, Greiner SM, Harvey ME, Zollman PJ, Russell SJ, Galanis E. A measles virus vaccine strain derivative as a novel oncolytic agent against breast cancer. Breast cancer research and treatment. 2006; 99:177-184.

28. Bai FL, Yu YH, Tian H, Ren GP, Wang H, Zhou B, Han XH, Yu QZ, Li DS. Genetically engineered Newcastle disease virus expressing interleukin-2 and TNF-related apoptosis-inducing ligand for cancer therapy. Cancer biology \& therapy. 2014; 15:1226-1238.

29. Xia M, Meng G, Jiang A, Chen A, Dahlhaus M, Gonzalez P, Beltinger C, Wei J. Mitophagy switches cell death from apoptosis to necrosis in NSCLC cells treated with oncolytic measles virus. Oncotarget. 2014; 5:3907-3918.

30. Takano M, Takahashi T, Agarikuchi T, Kurebayashi Y, Minami A, Otsubo T, Ikeda K, Kanazawa H, Suzuki T. Histochemical fluorescent staining of Sendai virus-infected cells with a novel sialidase substrate. Virology. 2014; 464-465C:206-212.

31. Siurala M, Bramante S, Vassilev L, Hirvinen M, Parviainen S, Tahtinen S, Guse K, Cerullo V, Kanerva A, Kipar A, Vaha-Koskela M, Hemminki A. Oncolytic adenovirus and doxorubicin-based chemotherapy results in synergistic antitumor activity against soft-tissue sarcoma. International journal of cancer Journal international du cancer. 2014.

32. Cuddington BP, Dyer AL, Workenhe ST, Mossman KL. Oncolytic bovine herpesvirus type 1 infects and kills breast tumor cells and breast cancer-initiating cells irrespective of tumor subtype. Cancer gene therapy. 2013; 20:282-289.

33. Lange S, Lampe J, Bossow S, Zimmermann M, Neubert W, Bitzer M, Lauer UM. A novel armed oncolytic measles vaccine virus for the treatment of cholangiocarcinoma. Human gene therapy. 2013; 24:554-564.

34. Gentschev I, Adelfinger M, Josupeit R, Rudolph S, Ehrig K, Donat U, Weibel S, Chen NG, Yu YA, Zhang Q, Heisig M, Thamm D, Stritzker J, Macneill A, Szalay AA. Preclinical evaluation of oncolytic vaccinia virus for therapy of canine soft tissue sarcoma. PloS one. 2012; 7:e37239.

35. He S, Li P, Chen CH, Bakst RL, Chernichenko N, Yu YA, Chen N, Szalay AA, Yu Z, Fong Y, Wong RJ. Effective oncolytic vaccinia therapy for human sarcomas. The Journal of surgical research. 2012; 175:e53-60.

36. Russell SJ, Federspiel MJ, Peng KW, Tong C, Dingli D, Morice WG, Lowe V, O'Connor MK, Kyle RA, Leung N, Buadi FK, Rajkumar SV, Gertz MA, Lacy MQ, Dispenzieri A. Remission of disseminated cancer after systemic oncolytic virotherapy. Mayo Clinic proceedings. 2014; 89:926-933. 
37. Ashkenazi A, Holland P, Eckhardt SG. Ligand-based targeting of apoptosis in cancer: the potential of recombinant human apoptosis ligand 2 /Tumor necrosis factor-related apoptosis-inducing ligand (rhApo2L/ TRAIL). Journal of clinical oncology : official journal of the American Society of Clinical Oncology. 2008; 26:3621-3630.

38. Zhao J, Wang SZ, Tang XF, Liu N, Zhao D, Mao ZY. Analysis of thermochemotherapy-induced apoptosis and the protein expressions of Bcl-2 and Bax in maxillofacial squamous cell carcinomas. Medical oncology. 2011; 28:S354-359.

39. Li C, Meng G, Su L, Chen A, Xia M, Xu C, Yu D, Jiang A, Wei J. Dichloroacetate blocks aerobic glycolytic adaptation to attenuated measles virus and promotes viral replication leading to enhanced oncolysis in glioblastoma. Oncotarget. 2015; 6:1544-1555.

40. Huang Q, Li F, Liu X, Li W, Shi W, Liu FF, O’Sullivan B, He Z, Peng Y, Tan AC, Zhou L, Shen J, Han G, Wang XJ, Thorburn J, Thorburn A, et al. Caspase 3-mediated stimulation of tumor cell repopulation during cancer radiotherapy. Nature medicine. 2011; 17:860-866.

41. Grandvaux N, tenOever BR, Servant MJ, Hiscott J. The interferon antiviral response: from viral invasion to evasion. Current opinion in infectious diseases. 2002; 15:259-267.

42. Honda K, Takaoka A, Taniguchi T. Type I interferon [corrected] gene induction by the interferon regulatory factor family of transcription factors. Immunity. 2006; 25:349-360. 